\title{
Leaves of Clerodendrum wallichi Merr. Exhibit Analgesic, Antioxidant and Cytotoxic Activities
}

\author{
Tufael Ahmed ${ }^{1}$, Farah Ashrafi Noor ${ }^{1}$, Mahfuza Afroz Soma ${ }^{1}$, Fahima Aktar ${ }^{2}$ \\ and Md. Ruhul Kuddus ${ }^{2}$ \\ ${ }^{1}$ Department of Pharmacy, State University of Bangladesh, 77 Satmasjid Road, Dhanmandi \\ Dhaka-1205, Bangladesh \\ ${ }^{2}$ Department of Pharmaceutical Chemistry, Faculty of Pharmacy, University of Dhaka \\ Dhaka-1000, Bangladesh
}

(Received: April 2, 2019; Accepted: May 20, 2019; Published: July 22, 2019)

\begin{abstract}
The present study was conducted to evaluate the analgesic, antioxidant and cytotoxic activities of leaves of Clerodendrum wallichii Merr. The analgesic activity of the crude methanolic extract of $C$. wallichii (MECW) was determined by tail flick- and acetic acid-induced writhing method in Swiss albino mice. In tail flick method, oral administration of MECW at $400 \mathrm{mg} / \mathrm{kg}$ body weight exhibited $362.19 \%$ elongation of pain response in experimental mice at $60 \mathrm{~min}$. The same dose of plant extract significantly $(\mathrm{p}<0.05)$ inhibited the acetic acid-induced abdominal constrictions in mice and this effect was dose-dependent. In addition, the methanol extract of $C$. wallichii (MECW) and its petroleum-ether (PESF), chloroform (CSF), dichloromethane (DCMSF) and aqueous (AQSF) soluble fraction were subjected to assay for determination of total phenol content, antioxidant and cytotoxic activities test by standard protocols. The highest amount of phenolic content was present in the MECW $(75.44 \pm 0.68 \mathrm{mg}$ of GAE/g of extract) while the AQSF displayed the highest free radical scavenging capacity ( $\mathrm{IC}_{50}$ value of $7.23 \pm 0.05 \mu \mathrm{g} / \mathrm{ml}$ ) as compared to $25.18 \pm 1.89 \mu \mathrm{g} / \mathrm{ml}$ exhibited by the standard butylated hydroxyl toluene (BHT). In brine shrimp lethality test, the number of surviving shrimp nauplii was counted and $\mathrm{LC}_{50}$ was assessed after $24 \mathrm{~h}$. Both MECW and its PESF exhibited maximum toxicity towards brine shrimp with $\mathrm{LC}_{50}$ value of $10.3 \pm 0.01 \mu \mathrm{g} / \mathrm{ml}$ with respect to standard vincristine sulfate (having $\mathrm{LC}_{50}$ of $0.45 \mu \mathrm{g} / \mathrm{ml}$ ). The results of the present investigations suggest that methanolic extract of $C$. wallichii possesses analgesic, antioxidant and cytotoxic activities, confirming the traditional use of the plant.
\end{abstract}

Key words: Clerodendrum wallichii Merr., analgesic, antioxidant, cytotoxic

\section{Introduction}

Medicinal plants have been considered as a vital source of lead molecules for the development of a wide range of most effective therapeutic agents (Newman et al., 2000, 2003; Butler, 2004). Moreover, the demand for plant based medicines, health products, food supplements, cosmetics etc. are increasing in both developing and developed countries, because herbal medicines are cost effective, less-toxic and have minimum side effects (Kalia et al., 2005). But, in most cases, there is no scientific data that could support the traditional uses of these medicinal plants (Moniruzzaman et al., 2019). Therefore, scientific evaluation of the biological activities of medicinal plants could help to justify their use in health care system (Foye et al., 2008).

Clerodendrum wallichii Merr. (Family: Lamiaceae) is an evergreen, bushy shrub which is widely distributed in all around the Indian subcontinent. In Bangladesh, the plant is usually found in the forests of Chittagong, Chittagong Hill 
Tracts and Moulavi Bazar. Traditionally, Chakma tribe in Bangladesh use the juice from its root for the treatment of fever while the Marmas and Murangs tribe take leaf extract for diarrhoea (Ganeshaiah, 2000). C. wallichii is an indigenous plant which has not been analyzed pharmacologically. Therefore, as a part of our ongoing research on Bangladeshi medicinal plants (Tabassum et al., 2019; Anjum et al., 2017) and considering the ethno-medicinal implications of $C$. wallichii, we have investigated this plant for assessment of analgesic, antioxidant and cytotoxic effects and we, here in, report the results of our preliminary studies.

\section{Materials and Methods}

Collection plant material and extraction: Whole plant parts of $C$. wallichii were collected from the hill tracts of Chittagong division, Bangladesh in May, 2018. The plant was then identified by the taxonomists present in Bangladesh National Herbarium, Mirpur, Dhaka. A voucher sample (DACB-46005) has been deposited in the herbarium for further reference.

After collection and identification, the clean plants were sun dried and ground to a coarse powder. Approximately $400 \mathrm{~g}$ powdered sample was soaked in $1600 \mathrm{ml}$ methanol in an amber bottle for 7 days with occasional shaking to facilitate the extraction of phytoconstituents. The whole mixture was then filtered by cotton plug followed by Whatman (No. 1) filter paper. The filtrate was further evaporated to dryness using a rotary evaporator at reduced temperature and pressure. The concentrated gummy mass was transferred to a clean beaker. Later, modified Kupchan method was followed to make different solvent fractions of this crude extract using various organic solvents (VanWagenen et al., 1993).

Drugs and reagents: Acetic acid, methanol, Tween-80 and vincristine sulfate were purchased from the local market of Dhaka, Bangladesh. Diclofenac sodium was collected from Incepta Pharmaceuticals Ltd., Bangladesh. Morphine was purchased from Gonoshasthaya Pharmaceuticals Ltd., Bangladesh. Normal saline was collected from the local market. DMSO was collected from Merck (Germany). All other reagents were of analytical grade.

Experimental animal: Swiss albino mice (25-35 g) of either sex aged 4-5 weeks were obtained from the Department of Pharmacy, Jahangirnagar University, Bangladesh. The mice were kept in the animal house of the State University of Bangladesh (SUB) and fed with standard rodent feed. The animals were kept for four days in the laboratory environment prior to use for the experiments. The Federation of European Laboratory Animal Science Association's guidelines and recommendations were followed to reduce the pain and stress of the experimental mice. Twelve Swiss albino mice were randomly divided into four groups of three animals in each group for each bioassay: positive control, negative control and two test groups receiving MECW at doses of 200 and $400 \mathrm{mg} / \mathrm{kg}$ of body weight.

Determination of central analgesic activity: The central analgesic activity of $C$. wallichii in mice was determined by the conventional tail flick method (Dewey et al., 1970). In this assay, two groups received the test samples (methanol extract of plant at 200 and $400 \mathrm{mg} / \mathrm{kg}$ body weight) while the positive and negative control received standard drug morphine ( $2 \mathrm{mg} / \mathrm{kg}$ body weight, intraperitoneal) and saline, respectively. After a stagnant period of 40 min, $1-2 \mathrm{~cm}$ of the tail of mice was inundated in warm water kept steady at $55^{\circ} \mathrm{C}$. The response time is the time required by the mice to avoid their tails was measured. An inertness time of $20 \mathrm{sec}$ was characterized as total absence of pain and the estimation was ceased to dodge damage to mice. The percent (\%) elongation of pain response was determined at $0,30,60$ and $90 \mathrm{~min}$ after administration of plant samples in mice.

Determination of peripheral analgesic activity: Peripheral analgesic activity of $C$. wallichii was evaluated by acetic acid-induced writhing method (Saha et al., 2009). Here, test samples and control drug were given orally to the mice at $0 \mathrm{hr}$ by means of a feeding needle. After $30 \mathrm{~min}, 1 \%$ acetic acid was 
administered via intra-peritoneal route to each mouse of all the groups to induce pain sensation. A $40 \mathrm{~min}$ interval between the oral administration of test materials and intraperitoneal administration of acetic acid was given to assure proper absorption of the administered samples. About $5 \mathrm{~min}$ after the administration of acetic acid, number of squirms or writhing were counted for each mouse for $10 \mathrm{~min}$.

Total phenolic analysis: The total phenolic content of the MECW, PESF, CSF, DCMSF and AQSF were determined by following the method of Skerget et al. (2005) using Folin-Ciocalteu reagent as oxidizing agent and gallic acid as standard.

Determination of antioxidant activity: The antioxidant activity of the plant extractives was determined employing DPPH (1,1-diphenyl-2picrylhydrazyl) free radical scavenging assay as described by Brand-Williams et al. (1995).

Determination of cytotoxic activity: The cytotoxicity of $C$. wallichii extractives was performed on brine shrimp nauplii using vincristine sulfate as standard (Meyer et al., 1982).

\section{Results and Discussion}

The present study was undertaken to evaluate the analgesic, antioxidant and cytotoxic activities of $C$. wallichii extractives and the results have been summarized in tables 1-3.

Table 1. Central analgesic activity of methanol extract of $C$. wallichi.

\begin{tabular}{|c|c|c|c|c|c|c|c|c|c|}
\hline \multirow{2}{*}{$\begin{array}{l}\text { Test } \\
\text { groups }\end{array}$} & \multirow{2}{*}{$\begin{array}{l}\text { Dose } \\
(\mathrm{mg} / \mathrm{kg})\end{array}$} & \multicolumn{4}{|c|}{ Mean of tail immersion \pm SEM } & \multicolumn{4}{|c|}{$\%$ Elongation of pain response } \\
\hline & & $0 \min$ & $30 \mathrm{~min}$ & $60 \min$ & $90 \min$ & $0 \min$ & $30 \mathrm{~min}$ & $60 \min$ & $90 \mathrm{~min}$ \\
\hline Control & - & $1.69 \pm 0.08$ & $1.85 \pm 0.19$ & $2.29 \pm 0.15$ & $2.14 \pm 0.14$ & - & - & - & - \\
\hline Morphine & 2 & $1.75 \pm 0.10$ & $8.57 \pm 0.12$ & $12.62 \pm 0.15$ & $12.98 \pm 0.14$ & 3.61 & 362.30 & 452.08 & 505.39 \\
\hline MECW & 200 & $1.67 \pm 0.13$ & $5.68 \pm 0.07$ & $9.05 \pm 0.15$ & $9.12 \pm 0.46$ & -1.44 & 206.24 & 295.97 & 325.71 \\
\hline MECW & 400 & $1.59 \pm 0.06$ & $7.21 \pm 0.28$ & $10.57 \pm 0.18$ & $9.55 \pm 0.38$ & -5.71 & 288.97 & 362.19 & 345.52 \\
\hline
\end{tabular}

Values are expressed as mean \pm SEM $(n=3), p<0.05$ significant when compared to negative control.

During central analgesic activity assay, the MECW exhibited dose-dependent pain reducing activity in experimental mice. The plant extract, at 200 and $400 \mathrm{mg} / \mathrm{kg}$ body weight, significantly $(\mathrm{p}<0.05)$ inhibited the pain response by $295.97 \%$ and $362.19 \%$ at $60 \mathrm{~min}$, respectively which were closed to standard drug morphine $(452.08 \%)$. In this experiment, the highest elongation of pain response (362.19\%) was observed by the plant extract at 400 $\mathrm{mg} / \mathrm{kg}$ body weight at $60 \mathrm{~min}$ whereas morphine showed a maximum elongation by $505.39 \%$ at 90 $\min$ (Table 1).

The pain reducing effects of C. wallichi extract on acetic acid-induced writhing method are shown in table 2. The tested plant extract, MECW (200 and $400 \mathrm{mg} / \mathrm{kg}$ body weight) and the standard diclofenac sodium $(50 \mathrm{mg} / \mathrm{kg}$ body weight $)$ significantly $(\mathrm{p}<0.05)$ reduced abdominal constrictions in mice.
The MECW at 200 and $400 \mathrm{mg} / \mathrm{kg}$ body weight inhibited the writhing response by $60.38 \%$ and $69.81 \%$, respectively as compared to $73.58 \%$ exhibited by diclofenac sodium. Both the tail flick and the writhing method are very useful techniques for the evaluation of central and peripheral analgesic activity of plant extract, respectively (Amir et al., 2004; Adeyemi et al., 2004). It is well known that the central analgesic action is mediated via inhibition of central pain receptors (Sharma et al., 2003; Khanna et al., 2003). Opiates such as morphine exert their analgesic activity by interacting with various central pain receptors (Wani et al., 2012). In our experiment, standard morphine caused significant analgesic effect in mice and the effect became more prominent as time increased. Similar effects were observed in case of the plant extract. The peripheral analgesic effect is generally mediated through inhibition of cyclooxygenase pathway or inhibition of nociceptors 
mediated pain responses (Amir et al., 2004; Duarte et al., 1988). In this study, C. wallichi extract showed dose-dependent inhibition of pain in mice model originated by both central and peripheral mechanisms. Further phytochemical investigations are required to isolate the components responsible for the activity.

Table 2. Peripheral analgesic activity of methanol extract of $C$. wallichi.

\begin{tabular}{|c|c|c|c|c|c|c|c|}
\hline \multirow[t]{2}{*}{ Test groups } & \multirow{2}{*}{$\begin{array}{c}\text { Dose } \\
(\mathrm{mg} / \mathrm{kg})\end{array}$} & \multicolumn{3}{|c|}{ Writhing count } & \multirow{2}{*}{$\begin{array}{c}\text { Number of writhing } \\
\text { Mean } \pm \text { SEM }\end{array}$} & \multirow[t]{2}{*}{$\%$ Writhing } & \multirow{2}{*}{$\begin{array}{l}\% \text { Inhibition of } \\
\text { writhing }\end{array}$} \\
\hline & & M1 & M2 & M3 & & & \\
\hline Control & - & 18 & 18 & 17 & $17.67 \pm 0.33$ & 100 & - \\
\hline Diclofenac sodium & 50 & 4 & 6 & 4 & $4.67 \pm 0.67$ & 26.42 & 73.58 \\
\hline MECW & 200 & 6 & 5 & 5 & $7.00 \pm 0.00$ & 39.62 & 60.38 \\
\hline MECW & 400 & 7 & 7 & 7 & $5.33 \pm 0.33$ & 30.19 & 69.81 \\
\hline
\end{tabular}

Values are expressed as mean \pm SEM $(n=3)$, $p<0.05$ significant when compared to negative control.

Table 3. Total phenolic content, antioxidant and cytotoxic activity of $C$. wallichi.

\begin{tabular}{lccc}
\hline Samples & $\begin{array}{c}\text { Total phenolic content } \\
(\mathrm{mg} \text { of GAE/g of extract) }\end{array}$ & $\begin{array}{c}\text { Antioxidant activity } \\
\mathrm{IC}_{50}(\mu \mathrm{g} / \mathrm{ml})\end{array}$ & $\begin{array}{c}\text { Cytotoxic activity } \\
\mathrm{LC}_{50}(\mu \mathrm{g} / \mathrm{ml})\end{array}$ \\
\hline MECW & $75.44 \pm 0.68$ & $47.81 \pm 6.19$ & $10.3 \pm 0.01$ \\
PESF & $24.34 \pm 0.44$ & $30.32 \pm 1.09$ & $10.3 \pm 0.01$ \\
CSF & $33.51 \pm 0.52$ & $26.92 \pm 0.35$ & $15.08 \pm 0.10$ \\
DCMSF & $60.45 \pm 0.13$ & $80.48 \pm 0.45$ & $26.01 \pm 0.08$ \\
AQSF & $74.58 \pm 0.04$ & $7.23 \pm 0.05$ & $13.00 \pm 0.06$ \\
VS & - & - & $0.45 \pm 0.00$ \\
BHT & - & $25.18 \pm 1.89$ & - \\
\hline
\end{tabular}

VS = Vincristine sulfate, BHT = Butylated hydroxyl toluene, GAE $=$ Gallic acid equivalent.

The antioxidant activity of $C$. wallichii was determined by using total phenolic content methods and DPPH free radical scavenging assay. As shown in table 3, the total phenolic content in MECW and its various solvent fractions varied from $24.34 \pm 0.44$ to $75.44 \pm 0.68 \mathrm{mg}$ of gallic acid equivalent (GAE)/g of extractives. The MECW and its AQSF had the highest value of $75.44 \pm 0.68$ and $74.58 \pm 0.04 \mathrm{mg}$ of GAE/gm of extractives, respectively followed by the DCMSF $(60.45 \pm 0.13 \mathrm{mg}$ of GAE/gm of extractives) and CSF (33.51 $\pm 0.52 \mathrm{mg}$ of GAE/gm of extractives). Similar trends were observed in case of the antioxidant activity assay. The AQSF showed the highest antioxidant activity with $\mathrm{IC}_{50}$ of $7.23 \pm 0.05 \mu \mathrm{g} / \mathrm{ml}$ followed by the CSF $(26.92 \pm 0.35 \mu \mathrm{g} / \mathrm{ml})$ and PESF $(30.32 \pm 1.09 \mu \mathrm{g} / \mathrm{ml})$ respectively, as compared to $25.18 \pm 1.89 \mu \mathrm{g} / \mathrm{ml}$ exhibited by the standard BHT
(Table 3). Phenolic compounds from natural sources are very well known for their ability to neutralize the free radicals and are good anti-oxidants (Kaur et al., 2002). Therefore, the anti-oxidant activities of the fractions of $C$. wallichi extract could be attributed to the presence of polyphenols and related phytochemicals in high quantity.

The highest cytotoxic activity was shown by both the MECW and its PESF with $\mathrm{LC}_{50}$ of $10.3 \pm 0.01 \mu \mathrm{g} / \mathrm{ml}$, which was comparable to the standard vincristine sulfate $(0.45 \pm 0.00 \mu \mathrm{g} / \mathrm{ml})$. This result could suggest the presence of active phytoconstituents having prominent cytotoxic activity. There have been several reports where phytochemicals such as flavonoids, saponins, steroids and alkaloids could possess cytotoxic and possible 
anti-cancer properties (Okigbo et al., 2009; Aziz et al., 2014; Zarin et al., 2016).

\section{Conclusion}

The whole plant extract of $C$. wallichii Merr. has been found to be effective in reducing pain in mice. In addition, the crude extract of $C$. wallichii and its different fractions showed prominent antioxidant and cytotoxic activities. Further studies are needed to isolate the bioactive compounds from this plant extracts which are responsible for the bioactivities.

\section{Acknowledgements}

The authors are grateful to State University of Bangladesh for providing laboratory support during the study.

\section{References}

Adeyemi, O.O., Okpo, S.O. and Okpaka, O. 2004. The analgesic effect of the methanolic extract of Acanthus montanus. J. Ethnopharmacol. 90, 45-48.

Amir, M. and Shikha, K. 2004. Synthesis and antiinflammatory, analgesic, ulcerogenic and lipid peroxidation activities of some new $2-[(2,6-$ dichloroanilino) phenyl] acetic acid derivatives. Eur. J. Med. Chem. 39, 535-545.

Anjum, A., Sultan, M.Z., Hasan, C.M. and Rashid, M.A. 2017. Antibacterial and cytotoxic constituents from Bridelia verrucosa Haines growing in Bangladesh. Dhaka Univ. J. Pharm. Sci. 16, 61-68.

Aziz, M.A., Alam, A.S., Ema, A.A., Akter, M. and Chowdhury, M.M.H., 2014. Analysis of secondary metabolites, antibacterial, brine shrimp lethality \&larvicidal potentiality of Microcos paniculata fruits. IOSR J. Pharm. Biol. Sci. 9, 50-58.

Brand-Williams, W., Cuvelier, M.E. and Berset, C.L.W.T., 1995. Use of a free radical method to evaluate antioxidant activity. LWT-FOOD Sci. Technol. 28, 25-30.

Butler, M.S. 2004. The role of natural product chemistry in drug discovery. J. Nat. Prod. 67, 2141-2153.

Dewey, W.L., Harris, L.S., Howes, J.F. and Nuite, J.A. 1970. The effect of various neurohumoral modulators on the activity of morphine and the narcotic antagonists in the tail-flick and phenylquinone tests. $J$. Pharmacol. Exp. Ther. 175, 435-442.
Duarte, I.D., Nakamura, M. and Ferreira, S.H. 1988. Participation of the sympathetic system in acetic acidinduced writhing in mice. Braz. J. Med. Biol. Res. 21, 341-343.

Foye, W.O. 2008. Foye's Principles of Medicinal Chemistry, Lippincott Williams \& Wilkins.

Ganeshaiah, K. N. 2000. UAS, Bangalore, India. Kailash, B. R., UAS \& ATREE, Bangalore, India. Indian Bioresource Information Network (IBIN), Department of Biotechnology, New Delhi, India.

Kalia, A.N. 2005. Text Book of Industrial Pharmacognosy, Oscar publication. New Delhi, India.

Kaur, C. and Kapoor, H.C. 2002. Anti-oxidant activity and total phenolic content of some Asian vegetables. Int. J. Food. Sci. Technol. 37, 153-161.

Khanna, N. and Bhatia, J. 2003. Antinociceptive action of Ocimum sanctum (Tulsi) in mice: possible mechanisms involved. J. Ethnopharmacol. 88, 293296.

Meyer, B.N., Ferrigni, N.R., Putnam, J.E., Jacobsen, L.B., Nichols, D.J. and McLaughlin, J.L. 1982. Brine shrimp: a convenient general bioassay for active plant constituents. Planta Med. 45, 31-34.

Moniruzzaman, M., Kuddus, M.R., Chowdhury, A.S. and Rashid, M.A. 2019. Antioxidant, antimicrobial, antidiarrheal and analgesic activities of Diospyros malabarica (Desr.) Kostel. Bangladesh Pharm. J.22, 27-33.

Newman, D.J., Cragg, G.M. and Snader, K.M. 2000. The influence of natural products upon drug discovery. Nat. Prod. Rep. 17, 215-234.

Okigbo, R.N., Anuagasi, C.L. and Amadi, J.E. 2009. Advances in selected medicinal and aromatic plants indigenous to Africa. J. Med. Plants Res. 3, 86-95.

Saha, A. and Ahmed, M. 2009. The analgesic and antiinflammatory activities of the extract of Albizia lebbeck in animal model. Pak. J. Pharm. Sci. 22, 7477.

Sharma, S., Jain, N.K. and Kulkarni, S.K. 2003. Inhibition of COX-1 enzyme potentiates opioid-induced antinociception in animal model of central nociception. Indian J. Pharmacol. 35, 21-26.

Skerget, M., Kotnik, P., Hadolin, M., Hras, A.R., Simonic, M. and Knez, Z. 2005. Phenols, proanthocyanidins, flavones and flavonols in some plant materials and their antioxidant activities. Food Chem. 89, 191-198. 
Tabassum, T., Bari, M.A., Kuddus, M.R. and Rashid, M.A. 2019. Analgesic, anti-diarrheal, anti-depressant, membrane stabilizing and cytotoxic activities of Bridelia verrucosa Haines. Bangladesh Pharm. J. 22, 50-55.

VanWagenen, B.C., Larsen, R., Cardellina, J.H., Randazzo, D., Lidert, Z.C. and Swithenbank, C.1993. Ulosantoin, a potent insecticide from thesponge Ulosa ruetzleri. J. Org. Chem. 58, 335-337.
Wani, T.A., Kumar, D., Prasad, R., Verma, P.K., Sardar, K.K., Tandan, S.K. and Kumar, D., 2012. Analgesic activity of the ethanolic extract of Shorea robusta resin in experimental animals. Indian J. Pharmacol. 44, 493-499.

Zarin, M.A., Wan, H.Y., Isha, A. and Armania, N., 2016. Antioxidant, antimicrobial and cytotoxic potential of condensed tannins from Leucaena leucocephala hybrid-Rendang. Food Sci. Human Wellness, 5, 65-75. 